\title{
عبد الرزاق السنهوري ومشروعه في التقنين
}

\section{دراسة وتقويم}

\section{*جم الدين قادر الزنكي}

إنَّ التفكير في بناء منهج إسلامي بديل عن المناهج المستوردة يفرض علينا نوعاً من القراءة والنظر في

الأوضاع التي تحكمنا والمناهج التي تسيّرنا، ذلك أن الحكم على شيئ إيباباً أو سلباً مرهون بتصوره كما هو. وعن تحاهل هذه الأوضاع والقفز على أنسجتها نشأت أخطاء وتراكمت تصورات ومواقف خاطئة، الأمر الذي يستدعي شدَّ النظر إلى أمهات القضايا التي تتباطح على ساحة الفكر الإسلامي وتتلاطم في سيره وحركته وتسوح في أجوائه. ونعني بالذات قراءة متأنية لمستتبعات الحماثة وأثرها على الفكر الإسلامي وعلى له أوضاعنا الراهنة من كل جوانبها ومناحيها، سعياً بذلك إلى تلافي الأخطاء المنهجية التي تكاد تترسب في أعماق تفكيرنا، وتحول دون تقديم البديل الإسلاميّ المناسب في الظرف المتاح.

ولقد كانت مسألة (التقنين) من جملة المسائل التي اجتذبتها تحديات الحداثة إلى مسرح الأحداث في العالم الإسلامي الحديث. ويمثل مشروع الأستاذ عبد الرزاق السنهوري1 في التقنين حلقة مهمة من سلسلة التطورات التي حدثت في هذا الصدد. فمشروعه يعدُّ من أبرز المشاريع القانونية التي أحدثت تغييراً جذرياً في مئي الحالة القانونية بين المسلمين، حيث لم يقتصر مشروعه على بلده (مصر) فقط، وإنما تجاوزه إلى ليبيا وسوريا والكويت والعراق، الأمر الذي يدعو الدارسين إلى إلقاء الضوء على هذا المشروع الضخم، لسبر منهجيته ومصدريته، والكليات العامة التي تحرك ساكنه، والمبادئ التي تهيمن عليه، تشريعاً وفقهاً وقضاءً.

\section{ترجمة الأستاذ عبد الرزاق السنهوري}

$$
\text { * ماجستير في الفقه وأصول الفقه من الجامعة الإسلامية العالمية بماليزيا (2000)، وطالب دكتوراه بالجامعة نفسها. }
$$

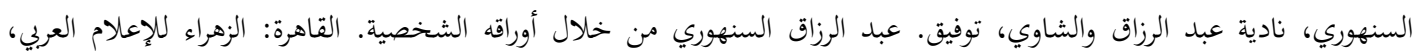

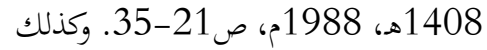

Hill, Enid, Al-Sanhuri And Islamic Law, Arab Law Quarterly, volume 3, JanuaryNovember 1988, pp, 191 -193. 
ولد الأستاذ الدكتور عبد الرزاق أحمد السنهوري في سنة (1895م) في الإسكندرية بمصر. درس الحقوق بالقاهرة وأخذ الليسانس سنة (1917م)، عين وكيلاً للنائب العام في المنصورة إلى سنة (1919م)، وفي سنة (1920م) عين مدرساً للقانون في مدرسة القضاء الشرعي، ثم سافر إلى فرنسا في بعثة دراسية للحصول على شهادة الدكتوراه في الحقوق، فكتب رسالته للدكتوراه في (القانون الإنجليزي)، ثم نال دكتوراه ثانية على رسالته الموسومة (الخلافة وتطورها لكي تصبح عصبة أمم شرقية) في جامعة ليون عام (1926م). تولى منصب وكيل وزارة التربية سنة (1939م)، ومنصب وزارة العدل (1944م)، ومنصب وزارة التربية سنة

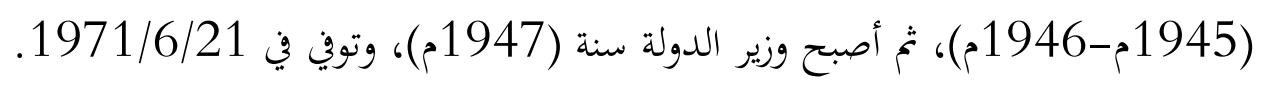

\section{التعريف ببعض المصطلحات الضرورية}

القانون: قواعد ملزمة تنظِّم سلوك الأشخاص في المجتمع، أو مجموعة القواعد والمبادئ والأنظمة التي يضعها أهل الرأي في أمة من الأمم لتنظيم شؤون الحياة الاجتماعية والاقتصادية، استجابةً متطلبات الجماعة

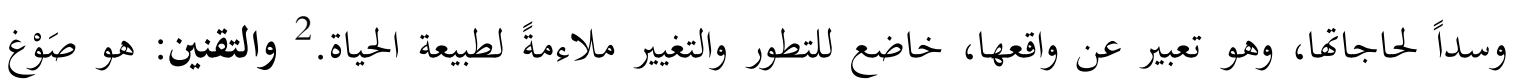

$$
\text { القانون في نصوص مرتبة، ووضع هذه النصوص في مجموعة مبوَّبة. } 3
$$

والشريعة: ما شرعه الله تعالى لعباده من العقائد والعبادات والأخلاق والمعاملات ونظم الحياة، في شعبها المختلفة، لتحقيق سعادقم في الدنيا والآخرة. ${ }^{4}$ والفقه: هو ما أدركه العقل البشري واستبطه من

$$
\text { الشريعة. فالشريعة إلهية، والفقه كسب بشريٌّ. }
$$

\section{نبذة مختصرة عن تأريخ التقنين في البلاد الإسلاميّة}

2 2 2

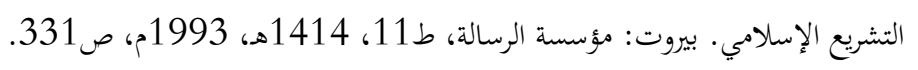

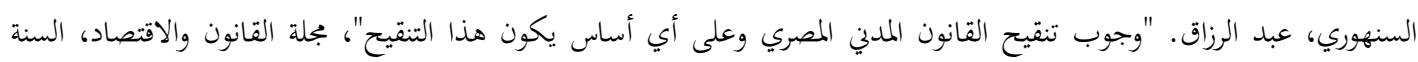

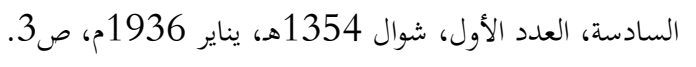

4

5 5 5 لمعرفة الصلة بين الفقه والقانون راجع: السنهوري، عبد الرزاق: فقه الخلافة وتطورها لتصبح عصبة أمم شرقية، ترجمة نادية السنهوري

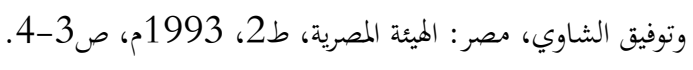


لقد حاول عبد الله بن المقفع في القرن الثاني الهجري/ الثامن الميلادي، أيام الخليفة العباسي أبي جعفر المنصور (775-713م)، إقناع الخليفة بتدوين الأحكام الشرعية المستمدَّة من الكتاب والسنة والقياس الأقرب للعدل، متخذاً من تضارب القضاء وتباين الأحكام حجته لهذه الدعوة، فعرض المنصور ذلك على الإمام مالك بن أنس، فامتنع قائلاً: "إنّ لككِّ سلفاً وأئمةً، فِإنْ رأى أمير المؤمنين، أعزَّ الله نصره، قرارَهم

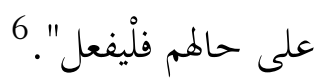

وفي منتصف القرن السادس عشر الميلادي جرَتْ في السلطة العثمانية محاولات لجمع اختياريٍّ

للمذهب الحنفيّ، وكلَّف السلطان سليمان القانويّ شيخ الإسلام أبا السعود العماديّ الكرديّ هذه المهمّة. 7 وتلت ذلك محاولة محمد أورنك زيب بهادر عالمكير في الهند في القرن السابع عشر الميلادي، حيث ألَّف لجنةً خماسيةً من مشاهير فقهاء الهند برئاسة نظام برهان بوري لتأليف كتاب جامع لظاهر رواية مذهب أبي حنيفة، ومّمّي الكتاب بـ "الفتاوى العالمكيرية"، ويقع في ستة أجزاء. إلا أنَّ هذه الفتاوى لم تأخذ طابع القانون الملزم، وضمَّت بين دفتيها مسائل العبادات.

ويبدو أن الفقهاء والأصوليين الأوائل كانوا يعارضون التدوين الرسميّ للأحكام الفقهية لأسباب

عديدة، هما:

1. الطابع الدينيّ لمصدر التشريع في الإسلام جعل الفقهاء يتورعون عن صياغة الأحكام الشرعية في صورة نظريات عامّة، رعايةً للتفاصيل التي وردت بها نصوص تشريعية خاصّة.

2. إيثار الفقهاء اتباع المنهج الاستقرائيّ الذي يتمشَّى مع سياق التفاصيل التي نصَّ عليها القرآن والسنة على اتباع المنهج التحليلي الذي يعمد إلى استخلاص المبادئ العامة من هذه النصوص.

$$
\begin{array}{r}
6 \\
8
\end{array}
$$


3. مراعاة جانب حرية "الاجتهاد" وما يكمن في ثناياها من حرية الضمير الديني ذاته، إذ التقنين مؤدٍّ

إلى تضييق نطاق الاجتهاد جرياً على العمل بقاعدة "لا مساغ للاجتهاد في مورد النص". 9

4. اعتقاد فقهائنا الأوائل أنَّ الصواب لا يتعين في إطار مذهب فقهيّ أو اجتهادات معينة فيما وراء الأحكام القطعية، فيكون الإلزام برأي اجتهاديّ بعينه إلزاماً بغير ملزم شرعاً، وهذا قبل عهد التدوين للسنة النبوية والتأليف في أصول الفقه، أما بعد ذلك فلا يخفى أن الدولة كانت تنتهج الالتزام بمذهب فقهي معين كالمذهب الحنفي مثلاً، وقد اتفقوا على أن حكم الحاكم في المسائل الحنافية يرفع الخلاف. 10 لكن بعد احتكاك الخلافة العثمانية بالغرب الذي كان قد بدأ حركة تدوين القانون شرعت الخلافة في القرن السادس عشر الميلاديّ في التفكير بمشروع التقنين، فنشطت حركة التدوين منذ صدور " خط كلخانه شريف " عن السلطان عبد المجيد في 1839م، وبلغت شأواً بعيداً بعد عام 1856م، لكن حركة التدوين

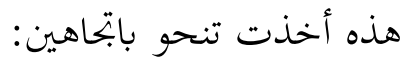

1. ابتحاه الاقتباس من القوانين الغربية المدوَّنة، لا سيّما القانون الفرنسي، فأصدرت السلطة العثمانية قانون العقوبات 1840م، وقانون التجارة 1850م، وقانون الأراضي 1858م، وقانون أصول المحاكمات 1878م، وقانون التجارة البحرية 1863م، وقانون أصول المحاكمات الجزائية 1879م، وقانون الإجراء 1906م، وكانت هذه القوانين مشتقة من القوانين الغربية. وكان "قانون الأراضي" قد شوَّه بعض أحكام الميراث الشرعيَّة، وذلك بمساواة الإناث للذكور في نص المادة 54، وإضافةً إلى ذلك لم يكرّس قانون الجزاء العثماني العقوبات الشرعيّة، بما فيها الحدود، ولم تحرّم الفائدة الربويّة. 11 2. واتجاه تقنين أحكامٍ من الشريعة الإسلاميّة، وذلك يتمثَّل في إصدار عملين اثنين هما:

$$
9
$$

10

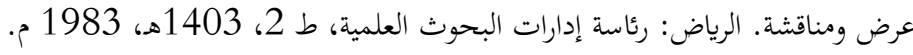
زيادة، طارق. دراسات في الفقه والقانون، مرجع سابق، صول94-100، ومحمد، محمد عبد الجواد. بحوث في الشريعة الإسلامية

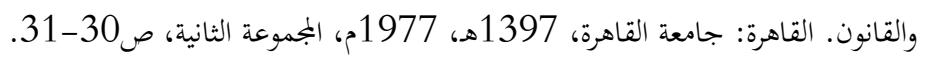


• إصدار "ججلَّة الأحكام العدليَّة" سنة (1293ه/ 1876م) والتي قُنْنت فيها أحكام المعاملات المدنيّة إلى جانب أحكام الدعوى وأصول المحاكمات القضائَّة ومسائل الإثبات، وكانت تتضمن 1869 مادة، وذلك برئاسة أحمد جودت باشا مع سبعة من الفقهاء. • إصدار "قانون العائلة" العثمانيّ في سنة (1336ه/ 1917م)، وترجع أهمية هذا القانون لأسباب ثلاثة هي: (1) أنه أول تقنين لمسائل الأحوال الشخصيّة من الشريعة الإسلامية. (2) وأنه لم يقتصر على قواعد المذهب الحنفيّ، بل اختيرت بعض قواعده من المذاهب الأربعة السُنيّة. (3) وكان هذا القانون يشتمل على قواعدَ قانونيّة خاصِّة باليهود والمسيحيّين. 12

ومن هنا حدثت ازدواجية معقدة في تركيبة التشريع والقضاء في البلاد الإسلامية، فالحلافة العثمانية بإصدارها للتنظيمات سنة (1255ه/1839م) تكون قد وضعت الأساس لهذه الازدواجية، وذلك بإصدارها القوانين المنقولة عن القوانين الغربيّة "الفرنسيّة". أما الازدواج القضائيّ فقد حدث في سنة (1860م) بإنشاء "المحاكم النظاميّة" الخاصة بتطبيق القوانين المستوردة، وصارت المحاكم القديمة يطلق عليها "المحاكم الشرعية"، وكانت وظيفتها مقتصرةً على مسائل الأحوال الشخصية للمسلمين. 13

وبتحر الإشارة إلى أن "بجلة الأحكام العدلية" كانت مطبَّقة في جميع البلاد الخاضعة للخلافة العثمانية، فيما عدا الجزائر التي احتلتها فرنسا منذ سنة (1830م) ومصر التي استقل بها محمد علي منذ سنة (1805م)، ولكنها ألغيت بعد ذلك تباعاً في تركيا الكمالية ولبنان (1934م)، وفي سوريا (1949م)، وفي العراق (1951م)، وفي الأردن (1976م)، ولم تطبق أصلاً في الجزيرة العربية واليمن. 14 وقد دوَّن الأستاذ قدري باشا في مصر (في النصف الثاني من القرن التاسع عشر) مجلةً مدنيةً وَفقاً للمذهب الحنفيّ أسماها (مرشد الحيران لمعرفة أحوال الإنسان) إلاًّ أنَّ الحكومة المصرية لم تتبنَّها بصورة ربميّة،

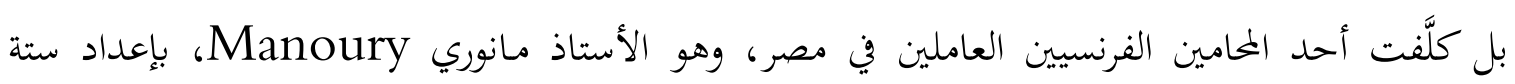

12

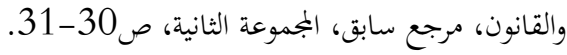

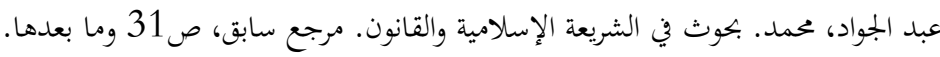

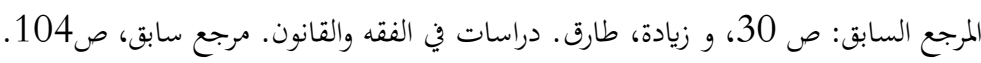


قوانين نقلت عن القوانين الفرنسية هي: القانون المدني والتجاري والبحري والجنائي والمرافعات والإجراءات الجزائية، ونشرت سنة (1875م) لتعمل بها المحاكم المختلطة المختصَّة بفصل الدعاوى بين الأجانب في مصر أو بين المصريين. وظلَّ الأمر كذلك حتى صدر القانون المديّ المصريّ الذي طبّق اعتباراً من 10/15/ 1949، والذي تمثَّل فيه دور الأستاذ عبد الرزاق السنهوري. 15

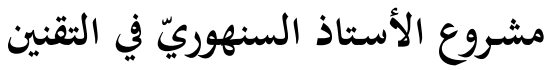

\section{1. موقفه النظريّ من التقنين والقانون المصري القديم}

إن الأستاذ السنهوري بدأ مشروعه في التقنين بدايةً نظريةً، حيث رسم في بحثه الموسوم: "وجوب تنقيح القانون المدني المصريّ" سنة (1936م) نظريته في تقنين التشريعات المصرية. ويمكن أن نلخص أنظاره في

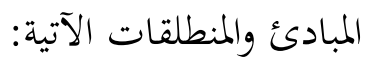

- إن القانون ليس مما يمكن حصره في بجموعة من النصوص، لأنه كائن حيّ ينمو ويتطور. وهو يتدرج في مراحل تطوره. وتقنينه هو تسجيله في وقت على الصورة التي وصل إليها، على أن لا تكون تلك الصورة فائيةً.

- القانون المكتوب ينمو إلى جانبه قانون غير مكتوب يتمثَّل في عمل القضاء والفقه، لذا لا يمكن أن

$$
\text { يكون التقنين تقييداً لتطور القانون ذاته. } 17
$$

- يكون التقنين ضرورياً إذا أريد توحيد القانون في بلد تعددت فيه القوانين، أو أريد إدخال قانون أجنبيّ في بلد يُحسب أنه في حاجة إلى هذا الإصلاح. ويكون التقنين مفيداً في مساعدة عامّة الناس

زيادة، طارق. دراسات في الفقه والقانون. مرجع سابق، ص104-238-105. ولمزيد من التفاصيل راجع: مصطفى الزرقا. المدخل الفنهي 
وخاصّتهم لتعرُّف الأحكام القانونية وإنارة الطريق الذي يجب أن يسلكه القانون في مراحل تقدّمه، كما يساعد على تقريب قوانين الأمم المتباينة، وهو أكبر معين على دراسة القانون المقارن. 18

وبناءً على هذه المنطلقات و تأسيساً على هذه الدعائم تبنَّ السنهوري الدعوة إلى ضرورة تنقيح التقنين باعتباره الوسيلة الوحيدة لتلافي أضرار التقنين. فالتقنين إذا كان بادئاً في صياغته أو ظهر عيبه عند التطبيق فلا بدَّ من تنقيحه، على أن هناك عاملاً آخر يشجِّع على التنقيح وهو : سرعة تقدم القانون المقارن.

والتقنين أمر لا يمكن إسناده إلى القضاء، وإلا خرج عن مهمته إلى مهمة التشريع، وهي مهمة لا يصلح لها، لأنه بطبيعته لا يضع حلولاً عامة، بل ينظر في أقضية خاصّة، لذا فإن من قال بفائدة التقنين فقد قال بضرورة التنقيح. ومن هنا دعا إلى ضرورة تنقيح القانون المدني المصري، لأنه قانون منتحل من القانون الفرنسي الذي ثبت كونه بحاجة إلى تنقيح شامل. 20 وقد ذكر الأسباب التي تدعو لمراجعة القانون المدني المصري وأعادها إلى أمرين: أ. كان التقنين المدني المصري في وضعه صورة منسوخة من التقنين الفرنسي، تسرَّع واضعه مانوري في صياغته، ولا يشمل كل أجزاء القانون المدني، حيث ينقصه القسم الخاص بالأحوال الشخصية. على أن هناك تقنيناً يطبق على المصريين وحدهم، وآخر يطبق عليهم وعلى الأجانب.

ب. الاستفادة من الشريعة الإسلامية والتجارب الخاصّة للقضاء المصري إلى جانب التشريعات الحديثة التي جلَّت منذ صدور القوانين المصرية، حتى يمكن بذلك التمشِّي مع التطورات الحديثة في علم القانون. 21 وقد أعاد عيوب التقنين المدني المصري القديم إلى الموضوع والشكل، فمن العيوب الموضوعية: الفضول والاقتضاب، والغموض، وتقليد القانون الفرنسي، والتناقض بين قواعده، والخطأ، والنقص، حيث إنَّ نصوصه

$$
\begin{array}{ll} 
& 18 \\
& \\
& \\
&
\end{array}
$$


لا تتناول إلا المعاملات دون الأحوال الشخصية. على أن هناك أحكاماً تُركت من غير إحالة إلى الشريعة أو القانون الفرنسي، فيتحيَّ القاضي في استقاء الحكم للوقائع المندرجة تحت هذه الدائرة. والنقص الأكبر هو قصور هذا التقنين عن بجاراة التقدم الهائل الذي قطع مراحله علم القانون في ذلك العصر.22 وقال في صدد بيان العيوب الشكلية:"ليست العيوب الشكلية بأقل وضوحاً وأضعف أثراً في تشويه تشريعنا المدني. وهي عيوب كثيرة متنوعة. منها ما يرجع إلى تبويب التقنين وترتيبه، وما يرجع إلى تعدد لغاته. ونضيف إلى ذلك عدم الدقة في التعبير القانوني، وضعف الأسلوب، وركاكة الترجمة عن الأصل الفرنسي". 23

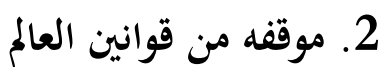

\section{لقد قسم السنهوريّ قوانين العالم المعروفة إلى أربع طوائف:}

أ- القوانين اللاتينية، ويمثلها القانون الفرنسي والمشروع الفرنسي الإيطالي. وقدقال السنهوريّ في تقدير المشروع الفرنسي الإيطالي: هو من الناحيتين الشكلية والموضوعية يفضُل التقنينين الفرنسي والإيطالي اللذين يراد به أن يحل محلهما. ولا شك في أن دراسة هذا المشروع ضرورية لنا عندما نريد مراجعة تشريعنا، إذ هو نواة صالحة لمراجعة ما كان مصدره لاتينيا من القوانين كقانوننا المصري.24 "والسر في نجاحه، على ما يظهر، يرجع إلى أنه محافظ على الروح اللاتينية في بساطتها ووضوحها، وهو يتمشى في الوقت ذاته مع النظريات الحديثة".

ب- القوانين الجرمانية، ويمثلها القانون الألماني والقانون السويسري. فوصف السنهوريّ القانون الألماني فقال: " يعدُّ القانون الألماني أضخم تقنين صدر في العصر الحديث. ولعل كلمة (الضخامة) هي اللفظ الذي يتفق مع الطابع الألماني. فيكاد يكون كل شيء لهم ضخما، رزقوا الضخامة في العلم والصناعة وفي الحرب وفي السياسة ويف التشريع، وامتازوا بالضخامة حتى في اللغة، وحتى في الجسم. والقانون الألماني خلاصة النظريات العلمية الألمانية مدى قرن كامل، وهو يبز من الناحية الفقهية أي قانون آخر، فقد اتبع

$$
\begin{aligned}
& 22 \text { 2 المرجع السابق، ص22-32. } \\
& 23 \\
& 24 \\
& 25
\end{aligned}
$$


طريقة تعتبر من أدق الطرق العلمية وأقربها للمنطق القانوني. ولكن هذا كان عائقا له عن الانتشار، فإن تعقيده الفني ودقته العلمية أقصاه بعض الشيء عن منحى الحياة العملية، وجعلاه مغلق التركيب عسير

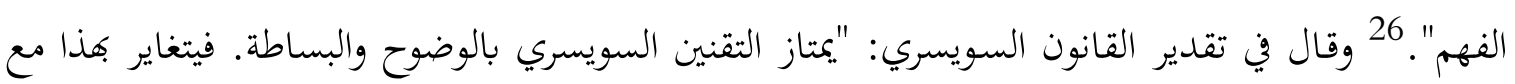
القانون الألماني المغلق المعقد. وهو يجمع إلى الوضوح والبساطة الدقة والتعمق، ثم يضم إلى كل ذلك الجدة

$$
\text { والتمشي مع أحدث النظريات العلمية". } 27
$$

ج- القانون الإنجليزي. وقد أغفل السنهوري تقدير القانون الإنجليزي قائلاً "ولما كان القانون الانجليزي غريباً عنا ولم نألفه، فمن البعيد أن نستفيد منه كثيراً.. لذلك نغفله. .". 28

د- الثريعة الإسلامية. 29 وحاول تقديرها في الجانب العلمي بأها تعدُّ في نظر المنصفين من أرقى النظم القانونية في العالم، ويضاهي منطقها منطق القانون الروماني. لذا يجب الرجوع إلى أحكامها في كثير من

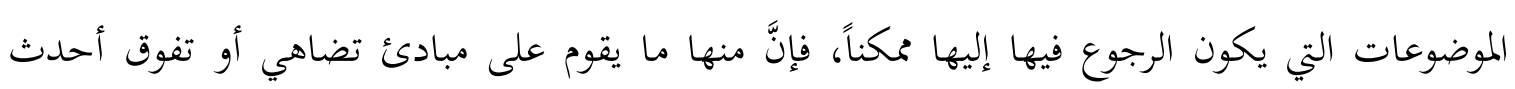
المبادئ القانونية المعاصرة، "ولا يجوز أن ننخدع هجذه النظرية السطحية التي يلقيها البعض على الشريعة الإسلامية، فيعتقد فيها عدم الصلاحية والجمود، فإها نظرة خاطئة. فالشريعة الإسلامية قد تطورت كثيراً، وتستطيع أن تتطور حتى تماشي المدنية الحاضرة". 30

\section{3. - 3نطلقاته في صياغة القانون الجديد}

إن أول ما انطلق منه الأستاذ السنهوري هو دعوته إلى جعل القانون شاملاً لجميع مناحي التشريع. فتحت عنوان "على أي أساس يكون تنقيح القانون المدني المصري" دعا إلى إدماج الأحوال الشخصية في التقنين المدني قائلاً:"التقنين الجديد يجب أن يكون شاملاً لكل المسائل... ولا نقصد بهذا أن ننقل تشريع الأحوال الشخصية من التشريعات الغربية. بل يجب أن يكون تشريعنا في هذه المسائل منقولاً عن الشريعة

$$
\begin{aligned}
& 26 \text { 2 } \\
& 27 \text { المرجع السابق، ص52. } \\
& 28 \\
& 2928 \\
& 30
\end{aligned}
$$


الإسلامية، مع جعله ملائماً لأن يطبق على غير المسلمين... فنحن إذن لا نريد بإدماج الأحوال الشخصية في القانون المدني أن ننقص من سلطان الشريعة الإسلامية، بل على العكس من ذلك، نحن نحبّ امتداد هذا السلطان إلى دائرة المعاملات نفسها، ولكننا نريد أن نحصل على مزية التقنين في جميع تشريعنا المدني". 31 وانطلق ثانياً من الإيمان بوجوب الاستقلال القانويّّ والتأكيد على ضرورة التحرر من التبعية في القانون مصمماً "أن مصر أصبحت مستحقة للتمتع بما تتمتع به كل أمة من الاستقلال بإدارة العدل في ديارها بين

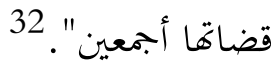

\section{4. المصادر المقتزحة لإجراء التنقيح على وفقها}

ذكر المصادر التي يستمد منها التنقيح، وحصرها في: التجارب الخاصة المتمثلة في القضاء المصري في مدى نصف قرن، وبحارب الأمم الأخرى المتمثلة في التقنينات الحديثة، والتقاليد الماضية في القانون المتمثلة في الشريعة الإسلامية.

وقد أكَّد أنَّ الاستمداد من القضاء المصري الذي هو صفوة الحياة العملية للمصريين لا يمنع الاستفادة من بحارب الأمم الأخرى. لا سيما في مجال تقدمها. بيْدَ أنه لاحظ أنه لا يجوز استمداد شيء من الأحوال الشخصية من دائرة القوانين الأجنبية، لما تختص به هذه الدائرة القانونية من خضوع للمعتقدات الدينية والعادات والتقاليد، وأسلوب الحياة الاجتماعية، مما يفترض أن لا تكون مشوبة بالتأثر بالغير. كما لاحظ أن أكثر ما يستفاد من التقنينات الحميثة هو من ناحية الشكل أسلوباً وتبويباً، إلى جانب المبادئ الموضوعية الصالحة للاستلهام منها، لا سيما في جانب الالتزامات، وذلك لأن أساسها المنطق البشري، وهو واحد لا يتغير، كما أن موضوع الالتزامات أكثر موضوعات القانون بتحرداً من الاعتبارات المحلية، على أن التمشي مع حركة التعامل الدولية والتحليق في جو التعميم والشمول لا يتحققان إلا بالاستمداد من الغير في هذا

$$
\begin{aligned}
& 31 \\
& 32 \\
& 33
\end{aligned}
$$


المجال. 34 ثم إنه لا يسع أمةً أن تنعزل في تقنينها عن تقنينات غيرها من الأمم، وإلا حرمت نفسها من ثمار التجارب المفيدة دون أن تستفيد من عزلتها شيئاً. والأمة الرشيدة مطلوب منها ألا تقلد غيرها، ولا تنقل عن تشريع أجنبي إلا ما يتلاءم مع حالثها. 35 و"يجب أن تنال الشريعة الإسلامية نصيباً كبيراً من عناية المشرع المصري عند تنقيح التقنين. فقد كانت شريعة البلد قبل العمل بالقوانين الحالية. ولا تزال شريعة البلد في قسم كبير من القانون المدني". 36 على أن استقاء القانون من الشريعة عمل يتفق مع التقاليد القانونية القديمة، ويستقيم مع النظر الصحيح من أن القانون لا يُخلق خلقاً، بل ينمو ويتطور، ويتصل حاضره بماضيه. 37 وينطلق السنهوري في موقفه من الاستمداد من الشريعة من بعدين اثنين:

أ. أن الشريعة الإسلامية بحاجة إلى حركة تجديد علمية ترتكز على دراستها طبقاً للأساليب العلمية الحديثة وفي ضوء القانون المقارن. ومن هنا اقترح السنهوري التمييز بين الأحكام الدينية والأحكام القانونية. وأنه ينبغي في دائرة الأحكام القانونية التمبيز بين الثوابت والمتغيرات. وهو يقصد بالأحكام الدينية أصول الدين والعبادات والأحكام الخاصة بالمسلمين، فهذه الأحكام تبقى محترمة في العقيدة والقلب، أما الأحكام القانونية فهي التي تقوم على أساس المنطق القانوين المخض. 38

ب. صلاحية الشريعة لمصدرية القانون على حالتها الراهنة، ويؤكد ذلك بقوله: "ومهما يكن من أمر الشريعة الإسلامية، وحاجتها إلى التجديد... فإنها -حتى في حالتها الراهنة- تصلح مصدراً خصباً يستمد منه المشرع المصري كثيراً من المبادئ القانونية في تقنينه الجديد...". 39 وشدَّ السنهوري تركيزه على أهمية مصدر "الإجماع" في عملية التقنين، وعدَّه مفتاح التطور في الشريعة، وأنه قد مرَّ بثلاث مراحل، في الأولى منها كان الإجماع شيئاً يصدر عن غير قصد، فقد كان عادة يألفها

$$
\begin{aligned}
& 34 \\
& 35 \\
& 36 \text { 3 المرجع السابق، ص113. } \\
& 37
\end{aligned}
$$

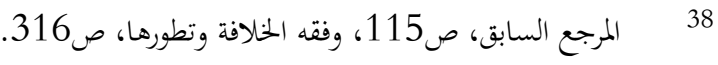

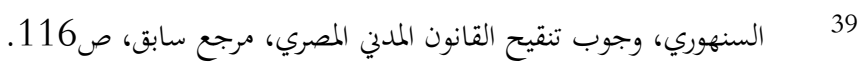


الناس، فتصير محترمة، أما في المرحلة الثانية فقد اختص الإجماع باتفاق الصحابة على رأي، ثم تطور في المرحلة الثالثة ليكون لازماً كذلك باتفاق الأجيال الأخرى غير الصحابة. وتحدث عن إمكان تطويره في مراحله المنطقية إلى اتفاق مقصود يتمثل في اجتماع المسلمين أو نوابهم لتشريع الأحكام، وبذلك يكون الإجماع عنصر التجديد في الشريعة، يحتفظ لها بمرونتها وقدرتا على التطور. 40

وحاول أن يوضِّح كيف اتصل المشرع السابق بالشريعة الإسلامية، ذاكراً أن التأريخ لا يُسعفه بشيء من المعلومات، لأن المشرع لم يحرر أعماله في أوراق تحضيرية. لكنه أكد أن اتصاله بها كان محدوداً، إذ الثابت أن (مانوري) هو الذي اقتبس من الشريعة، وقلده (موريوندو) فيما أخذه، وكل منهما كان محدود العلم بالشريعة الإسلامية.

\section{5 5 5 السنهوريّ لمشروعه التقنينيّ}

لقد أخذت نظرية السنهوريّ تحتل حيز الثنفيذ في صورة عملية عام (1936)، حيث أصدر مجلس الوزراء قراراً بتشكيل لجنة للقيام بهذه المهمة برئاسة مراد سعيد باشا وعضوية ثمانية من رجال القانون، فأنجزت بعض النصوص التمهيدية في مصادر القانون وتنازع القوانين. تم تألفت لجنة أخرى مكونة من رئيسها كامل صدقي باشا وعشرة أعضاء، وأنجزت النصوص الخاصة بالكفالة والشفعة. ثم اقترحت الوزارة سنة (1938) إسناد الأمر إلى أحد البارزين من رجال القانون، فاختير عبد الرزاق السنهوري باشا و(المسيو لامبير) من كبار رجال الفقه في فرنسا للقيام بهذه المهمة. فأنجزت اللجنة مهمتها وطبعت إنجازاتما سنة (1942)، حيث تم وضع المشروع التمهيدي للقانون المدني كاملاً. ثم عرض المشروع على البرمان من سنة (1945) إلى 27 مايو سنة (1946)، ثم أحيل إلى مجلس الشيوخ إلى سنة (1948)، ثم أحيل ثانية إلى مجلس النواب، وصدر المرسوم بالتصديق عليه بتأريخ 16 من يوليو سنة (1948)، وصدر القانون بالعمل به اعتباراً من 15 أكتوبر سنة (1949).

$$
\begin{aligned}
& 40 \\
& 41
\end{aligned}
$$

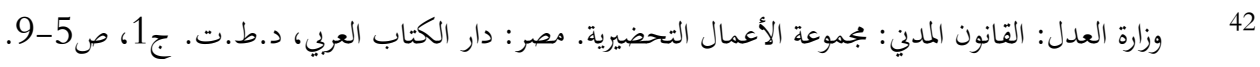


وقد ألقى السنهوري كلمة أمام اللجنة التشريعية بمجلس النواب قبيل إخراج المشروع الجديد قال فيها:

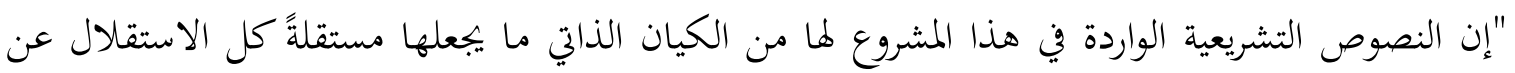
المصادر التي أخذت منها. ولم يكن الغرض من الرجوع إلى التقنينات الحديثة أن يتصل المشروع بهذه التقنينات المختلفة اتصال تبعية في التفسير والتطبيق والتطور، فإن هذا -حتى لو كان ممكنا- لا يكون مرغوبا فيه، فمن المقطوع به أن كل نص تشريعي ينبغي أن يعيش في البيئة التي يطبق فيها، ويحيا حياة قومية توثق صلته بما يحيط به من ملابسات، وما يخضع له من مقتضيات، فينفصل انفصالا تاما عن المصدر التاريخي الذي أخذ منه، أياً كان المصدر".43 ووصف السنهوري مشروع القانون الجديد بما يأتي: - إن طابعه هو الاعتدال، فهو يرضى الاستقرار، ويطاوع التطور، والاستقرار يتمثل في وصل الحاضر بالماضي. والتطور يترآى في تطلع الحاضر إلى المستقبل. 44 - الفقه والقضاء الفرنسيان هما النظام الأجنبي المرجوع إليه كما كانت الحال في عهد القانون المدني القديم. 45 وأكد ذلك بقوله: "إذا كنا نشعر اليوم بنزعة محمودة إلى تثبيت ذاتيتنا وتأكيد استقلالنا... فإن الواجب يقتضينا أن نذكر ذكر المعترف بالفضل والجميل ما نحن مدينون به للفقه الأجبي، وخاصة للفقه الفرنسي. فقد كان هذا الفقه التكأة التي عليها نرتكز، والنور الذي به هتدي، ولا زلنا مغمورين بفيضه حتى

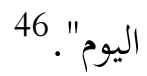

- الغالبية العظمى من أحكامه مستمدة من أحكام القانون المدني القديم ومن المبادئ التي أقرها القضاء المصري طوال سبعين سنة كاملة. 47

$$
\begin{aligned}
& 43 \text { 4 السنهوري. الوسيط في شرح القانون المدني الجديد. القاهرة: دار النهضة العربية، 1952، ج1، ص(هـ - و). } \\
& 44 \\
& \text { 4 } 45 \\
& \text { 4 } 46 \\
& 47
\end{aligned}
$$


وجواباً على سؤال، هو: أيشتمل التقنين الجديد على كل موضوعات القانون المدني، فيحتوي قانون الأسرة كما يحتوي قانون المعاملات؟ يقول السنهوري:" قامت صعوبات واضحة حالت دون أن يندرج في التقنين الجديد أحكام الأسرة، فإن هذه الأحكام ليس مصدرها فحسب الشريعة الإسلامية، بل إن لها مصادر دينية، وهي لم توحد في كل أجزائها بالنسبة إلى جميع المصريين". 48 وتحدث عما استقر عليه الأمر من مصادر التنقيح، ورتبها كالآتي: (أ) نصوص التقنين المدني القديم بعد أن هذبت وأضيفت إليها أحكام القضاء المصري طوال سبعين سنة. وهي تستغرق ثلاثة أرباع التقنين الجديد. (ب) الفقه الإسلامي. (ج) التقنينات الحديثة. 49

أما ما تمَّ استقاؤه من القانون الإسلامي فهو القديم من الفقه الإسلامي الذي استبقاه التقنين الجديد، والجديد من الفقه الإسلامي الذي استحدثه التقنين الجديد في صورة مبادئ عامة ومسائل تفصيلية.

وأشاد بأن الفقه الإسلامي أصبح مصدرا رسمياً للقانون المدنيّ، وهو المصدر الثالث. فالمادة الأولى نصت على أنه: "إذا لم يوجد نص تشريعي يمكن تطبيقه حكم القاضي بمقتضى العرف، فإذا لم يوجد فبمقتضى مبادئ الشريعة الإسلامية، فإذا لم توجد فبمقتضى مبادئ القانون الطبيعي وقواعد العدالة". 50 واستطرد قائلاً: "أما جعل الشريعة الإسلامية هي الأساس الأول الذي يبنى عليه تشريعنا المدني، فلا يزال أمنيةً من أعز الأماني التي تختلج بها الصدور، وتنطوي عليها الجوانح. ولكن قبل أن تصبح هذه الأمنية حقيقة واقعة ينبغي أن تقوم هضة علمية قوية لدراسة الشريعة الإسلامية في ضوء القانون المقارن. ونرجو أن يكون من وراء جعل الفقه الإسلامي مصدراً رسمياً للقانون الجديد ما يعاون على قيام هذه النهضة". 51 وقد برزت إشكالية جديدة في مسرح اتخاذ الشريعة مصدرا للقانون تتمثل في طبيعة تفسير النصوص المستفادة منها، فبين الأستاذ السنهوري طريقة هذا التفسير معيدا إياها إلى الاعتماد على مصدرين اثنين هما: (أ) القضاء المصري فيما يوجد له تفسير في هذا القضاء أو المبادئ التي استقر عليها هذا القضاء. وبيَّن

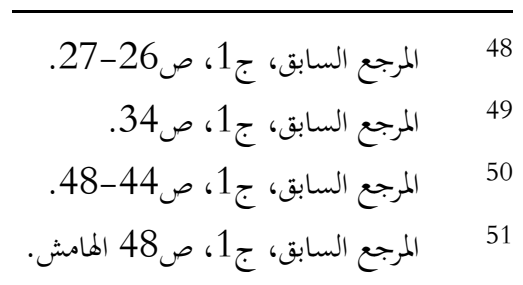


المدى الزمني لهذا القضاء المفسِّر بنصف قرن قبل صدور القانون الجديد، أي: بعد حلول القوانين الوضعية محل الشريعة الإسلامية (ب) وكتب الفقه الإسلامي، وبخاصة فيما لا يسعف القضاء المصري بتفسيره. وذلك شريطة عدم التقيد بمذهب معين من المذاهب الفقهية الإسلامية سواء كان من المذاهب الأربعة أو المذاهب الأخرى كالزيدية والإمامية، وشريطة التنسيق بين الأحكام المستقاة من الشريعة والمبادئ العامة التي يقوم عليها التشريع المدني في جملته. فلا يجوز الأخذ بحكم فقهي يتعارض مع هذه المبادئ، حتى لا يفقد التقنين المدني بتحانسه وانسجامه. وفي الترخص في الأخذ بالمذاهب جميعاً ما يجعل تحقيق هذا التنسيق أمرا ميسورا. 52 ورسم السنهوري المنهج المتبع في تفسير النصوص المستقاة من التقنينات الحديثة قائلاً بوجوب الفصل بين هذه النصوص ومصدرها التاريخي، فلا يرجع إلى المصادر الأجنبية في تطبيقها وتفسيرها، ذلك أن هذه النصوص قد اندججت في تقنين قائم بذاته وأصبحت ذات كيان ذاتي مستقل كل الاستقلال عن المصادر التي أخذت منها. فلا يرجع إليها إلا لأغراض علمية بحتة كالموازنة بين القوانين أو استقصاء أطوارها التاريخية. لذا فإن أية محاولة في تفسيرها وفقا لهذه المصادر هي محاولة مقضي عليها بالفشل، لأن هذه التقنينات كثيرة ومتنوعة، ولكل منها فجه وشرعته، وفقها وقضاؤه، وهي لا تخلو من التعارض والتنافر فيما بينها، فلا يجوز أن نرجع في تفسير تقنين متماسك متناسق إلى مصادر متضاربة متناقضة. 53 وأجمل الفروق الجوهرية بين التقنين القديم والجديد في أمرين اثنين: - ما استحدث من أحكام لم يكن معمولا بها في التقنين القديم. - ما قنن من أحكام معمول بها في القديم، لكن نصوصها كانت تقصر عن تأديتها، فعولجت عباراتا، وعدلت أساليبها. 54

5. السنهوري ونقل التقنين إلى البلاد العربية الأخرى

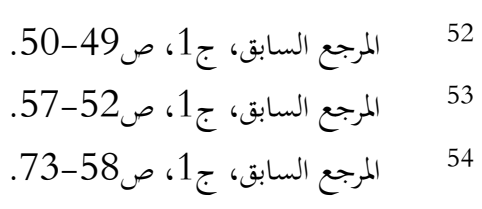


يأتي مشروع تقنين القانون المدني العراقي ثانيا من بين مشاريع السنهوري. وقد وصفت صلة السنهوري بالعراق بأها كانت قديمة تعود إلى سنة (1936)، حين كان يعمل عميدا لكلية الحقوق ببغداد. كما وصفت بغداد بأها المركز الرئيسي لمدرسة السنهوري وتلاميذه. لذا فإن قيامه بإعداد مشروع "القانون المدني العراقي" الذي صدر عام (1951) يعد من أروع أعماله. وقد جاء في الأسباب الموجبة لهذا التقنين: "قد رؤي أن يكون المشروع مثالاً لما ينبغي أن يكون عليه التقنين المدني في البلاد العربية، فجعل مزاجاً متآلفاً يجمع بين قواعد نقلت عن الشريعة الإسلامية، وقواعد نقلت عن التقنينات الغربية، وهو بتكوينه هذا يهكم التنسيق بين هذين المصدرين، فيتسع لمواجهة أوضاع الحضارة الحديثة، ويستحثُ الجهود لدراسة الفقه الإسلامي دراسة مقارنة ترده إلى ربيع حياته، وتمكنه من مسايرة هذه الأوضاع". 55

وبفعل أن بجلة الأحكام العدلية كانت هي قانون العراق فإن التقنين العراقي أخذ طابع الانتماء إلى الفقه الإسلامي أكثر بكثير من التقنين المصري، 56 لكن الأمر الغريب أنه جعل مصدر التفسير للقانون العراقي هو "الفقه والقضاء في العراق وفي البلاد الأجنبية التي تتقارب قوانينها مع القوانين العراقية"، 57 فيبدو أنه استبدل الفقه والقضاء في البلاد الأجنبية بالمصدر الثاني لتفسير القانون المصري الذي هو كتب الفقه الإسلامي. ويرى بعض الباحثين أن التقنينين المصري والعراقي كانا بمثابة مرحلة تمهيدية لتقنين الفقه الإسلامي، فقد قال السنهوري بعد صدورهما: "الهدف الذي نرمي إليه هو تطوير الفقه الإسلامي وفقا لأصل صياغته، حتى نشتق منه قانونا حديثا يصلح للعصر الذي نعيش فيه.. وليس القانون المصري أو القانون العراقي الجديد إلا قانونا مناسبا في الوقت الحاضر لمصر أو العراق. والقانون الدائم النهائي لكل من مصر والعراق، بل لجميع البلاد العربية، إنما هو القانون المدني الذي نشتقه من الشريعة الإسلامية بعد أن يتم تطويرها".

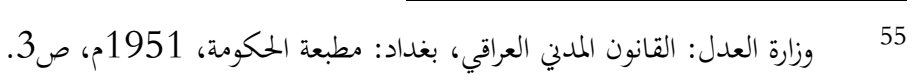

56 Saleh, Nabil, "Civil Codes of Arab Countries; The Sanhuri Codes", Arab Law Quarterly Volume8, January, 1993, December,1993, P163.

$$
\text { وزارة العدل: القانون المدني العراقي، مرجع سابق، صباد. }
$$

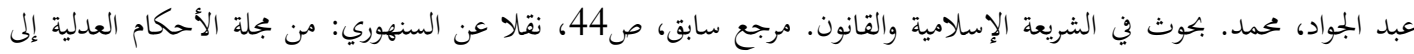

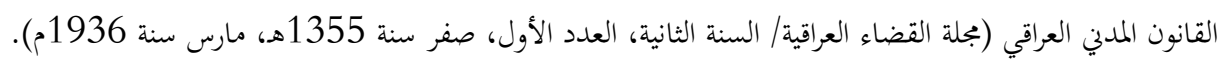


وجاء مشروع تقنين القانون المدني السوري إلى التنفيذ سنة (1949)، وقد كان نسخة من المشروع السابق، 59 لكن انطبع على صورة أوسع بطابع الشريعة الإسلامية، حيث إن (المجلة) كانت هي القانون السائد في سورية آنذاك، فساعد ذلك على طبع التقنين هناك بصبغة الشريعة الإسلامية. وقد جاء في مواد القانون أن الشريعة الإسلامية هي المصدر الثاني بعد نصوص القانون، وقبل العرف، على أن التفسير القضائي لكلمة (العرف) بيَّن أن المراد منها هو القانون الإسلامي. 60

ويأتي مشروعه في تقنين القانون الليبيّ بعد استقلالها سنة (1956). فصدرت القوانين المدنية والتجارية والمرافعات والعقوبات والإجراءات الجنائية بعجلة غير معهودة مما أدى إلى وقوع أخطاء مادية مضحكة في هذه القوانين. 61

وأخيراً جاء مشروعه في تقنين القانون الكويتي. فضيق من نطاق تطبيق (المجلة)، بإضافته الجزء الخاص بالالتزامات في القانون المدني المصري إلى القانون التجاري سنة (1961)، مع بقاء (المجلة) موقع التنفيذ في كثير من أحكامها إلى سنة (1981).

\section{استراتيجية السنهوريّ في تطبيق مبادئ الشريعة الإسلامية}

59 أعاد الشيخ مصطفى الزرقا الفرق بين القانون المصري والقانون السوري إلى اختلاف في ترتيب درجات المستندات التشريعية، حيث إن

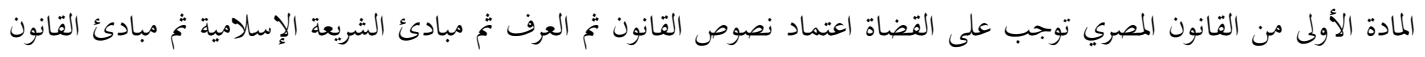

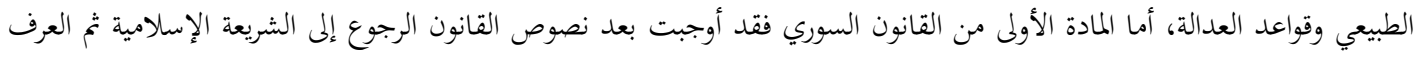

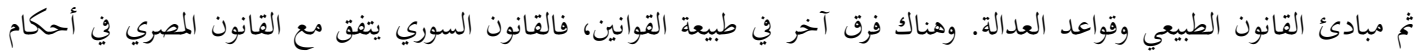

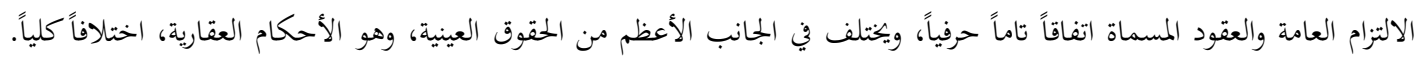

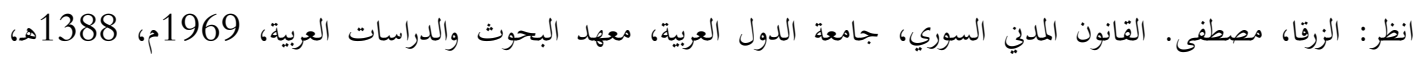

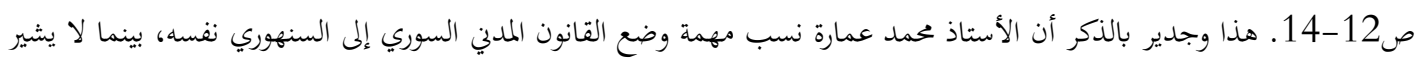

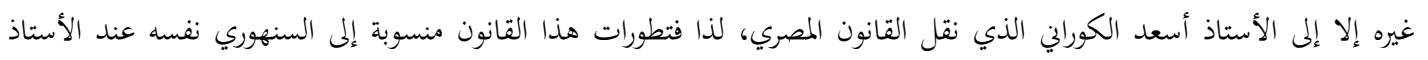

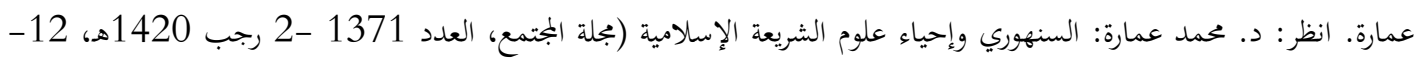

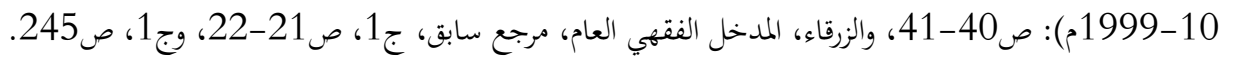

60 Saleh, Nabil, "Civil Codes of Arab Countries; The Sanhuri Codes”, P163.

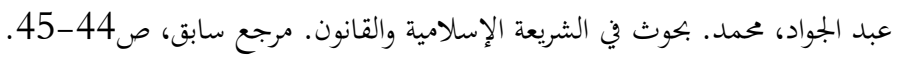

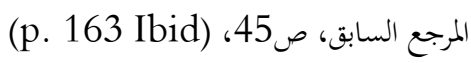


لا تستوي النظرة الكلية في أعمال السنهوري ومشاريعه في التقنين ولا تكتمل إلا بمعرفة استراتيجيته التي قصد إليها في تطبيق الشريعة الإسلامية. فتطبيق الشريعة الإسلامية في نظر السنهوري أصعب مشكلة، وربما كانت العائق الأول لإعادة الحلافة الصحيحة، وتتمثل هذه المشكلة في عقبتين اثنتين: - لكي يكون تطبيق الشريعة مكفولا لا بد من توفير المساواة التامة بين المسلمين وغير المسلمين بشكل لا يترتب عليه انتقاص من حريتهم الدينية.

- بالنسبة للمسلمين أنفسهم لا يمكن تطبيق التشريع الإسالامي إلا بعد إدخال ما يستلزمه التطور في بعض أحكامه، وخاصة المتعلقة منها بمجالات الاقتصاد والمعاملات العقارية، ليصبح متجاوبا مع مقتضيات الحضارة الحديثة.

ولكي تستبدل الشريعة الإسلامية بهذه القوانين فإن تطوير الفقه الإسالامي يجب أن يشمل مرحلتين: مرحلة علمية، ومرحلة عملية.

- أما المرحلة العلمية فتتمثل في دراسة الشريعة في ضوء القانون المقارن، 64 ونقطة البداية هي التفريق بين المجال الديني المُض والمجال القانوني في الشريعة الإسلامية، وكذلك التمييز بين الثوابت والمتغيرات في الدائرة القانونية.

ويمكن أن يمَّ هذا العمل بمرحلة الجهود الفردية ثم مرحلة الجهود الجماعية. على أن يقوم بدراسات جدية رجال مؤهلون في تاريخ الفقه ومنهج الشريعة الإسلامية. 65

$$
\text { السنهوري. فقه الخلافة وتطورها. مرجع سابق، ص315. }
$$

لقد انبثقت محاولة السنهوري في دراسة الفقه الإسلامي ومحاولة تقنينه من منطلق مقارنته بالقانون الوضعي، بينما انطلق آخرون من زاوية 64

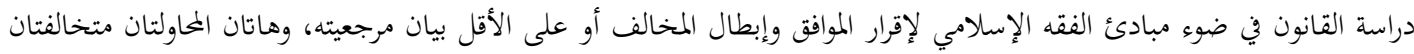

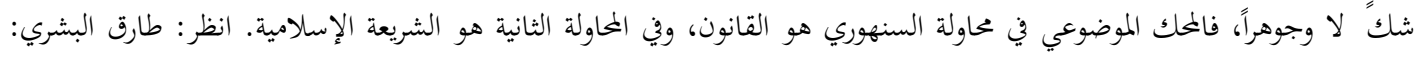

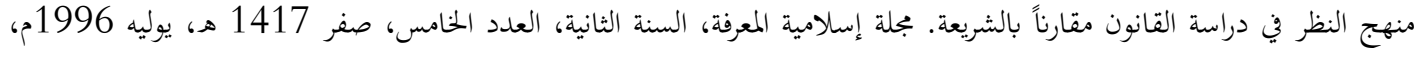
ص

$$
\text { السنهوري. فقه الخلافة وتطورها. مرجع سابق، ص316. }
$$


ومن هنا دعا إلى إنشاء معهد خاص لدراسة الفقه وتدريسه، و"الأساس في هذه الدراسة أن تكون دراسة مقارنة، فيدرس الفقه الإسلامي في ضوء القانون المقارن. ويعنى في هذه الدراسة بأمرين جوهريين، أولمما: أن تدرس نشأة الفقه الإسلامي دراسة دقيقة... وثانيهما: أن تدرس مذاهب الفقه الإسلامي المختلفة، السني والشيعي والخارجي والظاهري، وغير ذلك من المذاهب، دراسة مقارنة لنستخلص منها وجوه النظر المختلفة".

ويمثل كتابه (مصادر الحق في الفقه الإسلامي) الناحية العملية لدعوة الأستاذ السنهوري هذه في دراسة الفقه الإسلامي، حيث عمد في هذا الكتاب إلى معالجة أهم الموضوعات وأدقها في الفقه الغربي في إطار الفقه الإسلامي، مبتغيا بذلك وضع الفقه الإسلامي إلى جانب الفقه الغربي فيما هو مهم جوهري، وفيما هو دقيق خفي.67 وقد أخذ على نفسه في هذا الكتاب رسْمَ طريقة بحث علميةٍ صحيحة من غير أن يعنيه حشد المعلومات الدقيقة في الفقه والقانون، وأن يكون أسلوب التناول أسلوب الفقه الغربي، لكن المصادر التي يستند إليها البحث هي المصادر الإسلامية، يضاف إلى ذلك الرجوع إلى المصادر المعاصرة وبكوث المستشرقين ممن كتبوا في الفقه الإسلامي، وإن كان يعتقد أن أكثر الذين كتبوا من المستشرقين لم يكونوا من رجال القانون. كما أخذ عليها أن يبرز فروق الصنعة والأسلوب والتصوير بين الفقه الإسلامي والفقه الغربي، ليحتفظ الفقه الإسلامي بطابعه الخاص، حيث إن إخفاء هذه الفروق لا يكسب الفقه الإسلامي قوة، بل لعله يبتعد به عن جانب الجدة والإبداع، وأن يسعى إلى تحديد التحاه الاجتهاد الفقهي في مراحله المتعاقبة، لبيان سير الاجتهاد توصلاً إلى متابعة تطوراته إمكاناً وفعلاً. 68

ونتيجةً لاتباع هذه المنهجية نتلمس أثرين اثنين برزا في أفكار الأستاذ السنهوري، وهما:

أ. إن القانون العام في الفقه الإسلامي أقل تطورا من القانون الخاص.فهو لا يزال في مراحله الأولى لم يقطع شوطا كافيا في ميدان التقدم. وأعاد السبب في ذلك إلى: استبداد الحكومات المتعاقبة في الإسلام التي

$$
66
$$

السنهوري، عبد الرزاق. مصادر الحق في الفقه الإسلامي: دراسة مقارنة بالفقه الغربي، مرجع سابق، دار الهنا، 1953-1954م.

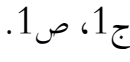

$$
\begin{aligned}
& \text { المرجع السابق، ج1، ص2-3. }
\end{aligned}
$$


كانت مهمتها إخماد أي حركة فقهية تقيم أصول الحكم على أسس من الحرية السياسية والحقوق العامة الديمقراطية. أما القانون الخاص في الفقه الإسلامي فيعود تقدمه إلى أن الحكومات المستبدة لم يكن يضيرها

تقدمه.

ب. إن القانون الجنائي في الفقه الإسلامي لم يتقدم في أصوله وأحكامه تقدم القانون المدني، بل بقي باب التعزير واسعا يدخل منه التشريع والقضاء والفقه لتقرير المبادئ الحديثة في القانون الجنائي، فإن الفقه الإسلامي في حالته الحاضرة لا يعرض لهذه المبادئ بإثبات أو نفي، بإقرار أو معارضة. 70

- وأما في المرحلة العملية فقد ارتآى الأستاذ السنهوري إلى اتخاذ سياسة التدرج في تطبيق الشريعة، فنبدأ بتقنين الأحوال الشخصية، ثم نتقدم خطوة أخرى نحو القوانين المتعلقة بالأحوال العقارية، ويمكن كذلك أن نبدأ الخطوة الأولى بتقرير مبدأ دستوري يجعل الشريعة هي القانون العام، وبذلك يتعود القضاة الرجوع إلى الفقه الإسلامي، ثم تكون الخطوة الثانية إلغاء القوانين المستوردة لتطبق بدلها الأحكام الإسلامية، وما يبقى من قوانين مستوردة يجب تطوير الفقه الإسلامي على شاكلتها حفاظاً على استقرار العلاقات القانونية. أما التغيير المفاجئ فلا يجدي شيئا، لما يسببه من زعزعة استقرار العلاقات القانونية. 71

\section{تحليل وتقويم}

إذا كان المشروع الذي سبق عرضه يبدأ خطوته الأولى من سنة (1936) عندما كتب الأستاذ السنهوري بحثه: "وجوب تنقيح القانون المدني المصري" فإن الباعث عليه قد سبق ذلك، وقد أعاد السنهوري نفسه (إشارة الابتداء) إلى سنة (1932م) عندما عقد بمدينة لاهاي (المؤتمر الدولي للقانون المقارن) الذي دعا فيه السنهوري فقهاء القانون الدولي إلى اعتماد الشريعة الإسلامية بوصفها منظومة قانونية متميزة. 72

$$
\begin{aligned}
& 6969 \\
& \text { 7 } 70
\end{aligned}
$$

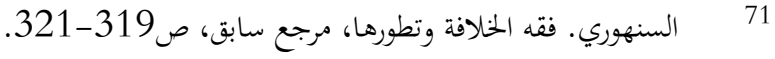

$$
\begin{aligned}
& 7272 \\
& \text { 1999م، ص40. }
\end{aligned}
$$


ومن هنا بدأ الأستاذ السنهوري يركز على مصدرية الشريعة الإسلامية في التقنين المدني الجديد. بيْدَ أنَّ الشريعة الإسلامية في إطلاقاته لا تأتي بمعنى الوحي الإلهي المعصوم، بل هي الفقه الإسلامي في إطار الملابسات التأريخية والمغرافيّة والأبعاد الحضارية، فهي تشكل تثاقفيّ حضاري، لا يقتصر على دين واحد، بل متكون من وحدات دينية متعددة، على أها رديف (الشرق) وثقافته. فيقول في مقدمة كتابه (نظرية العقد): "إني لم أغفل إلى جانب ذلك -يعني: القضاء المصري والتقنينات الحديثة- الشريعةً الإسلامية، شريعةً الشرق، ووحي إلهامه، وعصارة أذهان مفكريه؛ نبتت في صحرائه، وترعرعت في سهوله ووديانه، فهي قبس من روح الشرق، ومشكاة من نور الإسلام. يلتقي عندها الشرق والإسلام، 73 فيضيء ذلك بنور هذا، ويسري في هذا روح ذلك، حتى ليمتزجان ويصيران شيئا واحدا. هذه هي الشريعة الإسلامية، لو وطِّئت أكنافها، وعبّدت سبلها، لكان لنا من هذا التراث الجليل ما ينفح روح الاستقلال في فقهنا ويف قضائنا وفي تشريعنا، ثم لأشرفنا نطالع العالم بهذا النور الجديد، فنضيء به جانبا من جوانب الثقافة العالمية في القانون".

وتلمس أثر هذا التفكير واضحاً إذا قارنت بين دعوته الأولى إلى تقنين الأحوال الشخصية باعتبار أن التقنين القديم ينقصه ذلك، تم اعتذاره عن تقنينها في القانون الجديد، حيث عدَّ - في دعوته الأولى - محاولته تقنينَ الأحوال الشخصية من مبررات تنقيح التقنين القديم بقوله:" التقنين الجديد يجب أن يكون شاملا لكل المسائل.. ولا نقصد بهذا أن ننقل تشريع الأحوال الشخصية من التشريعات الغربية. بل يجب أن يكون تشريعنا في هذه المسائل منقولاً من الشريعة الإسلامية، مع جعله ملائماً لأن يطبق على غير المسلمين"، 75 ثم

يلاحظ أن الشرق والإسلام يلتقيان عند مصطلح (الشريعة الإسلامية) في نظر الأستاذ السنهوري، مما يوحي بأن الشريعة الإسلامية في

$$
\text { إطلاقاته هي أوسع من الوحي الإسلامي ومن الفقه الإسلامي أيضاً. }
$$

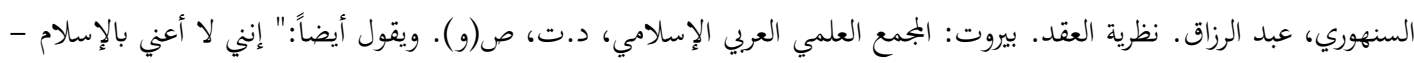
74

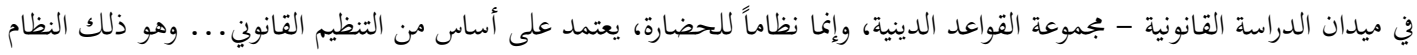

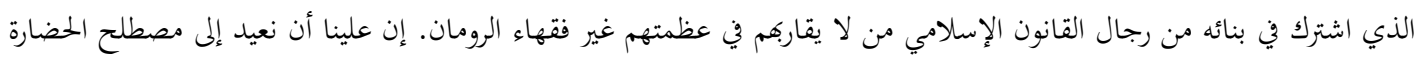

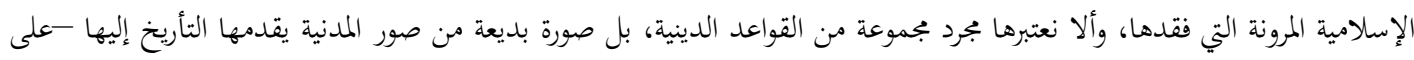

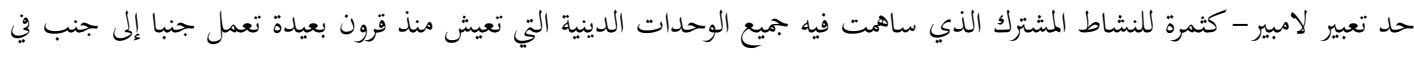

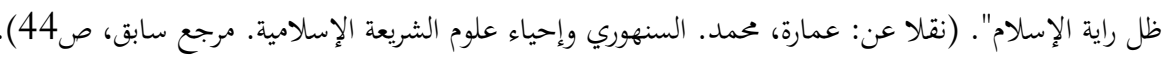

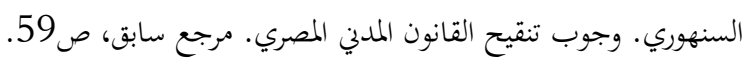


عاد بعد التقنين يقول: "قامت صعوبات حالتُ دون أن يندرج في التقنين الجديد أحكام الأسرة، فإن هذه الأحكام ليس مصدرها فحسبُ الشريعةً الإسلامية، بل إن لها مصادرَ أخرى دينيةً. 76

ثم إن (الشريعة الإسلامية) كمصدر من مصادر التقنين تندرج تحت التعميم الذي ذكره الأستاذ السنهوري قبيل إخراج المشروع الجلديد، حيث قال: "إن النصوص التشريعية الواردة في هذا المشروع لها من الكيان الذاتي ما يجعلها مستقلةً كلَّ الاستقلال عن المصادر التي أُخذت منها... فينفصل التقنين الجديد انفصالاً تاماً عن المصدر التأريخي الذي أخذ منه، أياً كان المصدر". 77

وامتداداً لهذه النظرية اعتمد في تفسير النصوص المستقاة من الشريعة على اللجوء أولاً إلى القضاء المصري ومبادئه ثم إلى كتب الفقه الإسلامي في مشروعه المصري، ثَُّّ ألغى الرجوع إلى الفقه الإسلامي في مشروعه العراقي، على أنه ذكر شرط الموافقة لمبادئ القانون فيما يؤخذ من هذه الكتب، وبهذا أنشأ فصلا وتمييزا بين هذه النصوص المستقاة من الفقه الإسلاميّ وبين مصادرها التاريخية، كل ذلك ليحقق الاستقلال الذي قصد إليه في صياغة القانون الجديد.

ولقد كان يؤمن الأستاذ السنهوري بأن القانون "ليس مما يمكن حصره في دفتي كتاب، أو في ججموعة من النصوص..فالقانون كائن حي، ينمو ويتطور في البيئة التي نشأ فيها، وهو أكثر مرونةً من أن يعيش في نصوص جامدة، ما دامت الحياة في تطور مستمر ..فليس للقانون ناية، إلا إذا قيل إن العالم إذا وصل في تقدمه إلى مرحلة معينة، بلغ الغاية من الكمال، وركد بعد ذلك لا يتطور". 79 وهذا اقتضاه أن يقول في كتابه (مصادر الحق في الفقه الإسلامي) وهو بصدد صياغة نظريات قانونية من الفقه الإسلامي: "إن فكرة المشروعية ليست أمراً ثابتاً، بل هي قد تختلف فيها الأنظار، ثم هي فكرة تتطور، فما كان غير مشروع

$$
\begin{aligned}
& 76 \text { السنهوري. الوسيط، مرجع سابق، ج1، ص26. } \\
& 77 \\
& 78 \text { المرجع السابق، ج1، ص49-40-50. } \\
& 7978 \text { السنهوري. وجوب تنقيح القانون المدني المصري، مرجع سابق، ص30. }
\end{aligned}
$$


بالأمس قد يكون مشروعاً اليوم، وما كان مشروعاً من قبل قد يكون بعد ذلك غير مشروع"، 80 الأمر الذي فسره البعض بالتشكيك في مبدأ المشروعية العليا في التشريع الإسلامي. 81

وجدير بالذكر أن الأستاذ السنهوري في كل مراحله التنظيرية والعملية لم يكن يطلق عنان الدعوة إلى التمسك بما أسماه (الشريعة الإسلامية)، فهو دائماً يؤكد على أن من أحكامها ما هو صالح للتطبيق، وأن منها ما يضاهي أحدث النظريات وأقومها في التقنين الحديث، فهو دائماً يؤسس نظريته في الاستمداد من الشريعة على الانتخاب والاختيار من هذه الدائرة، ولذلك أتت دعوته إلى توسيع دائرة الاستقاء الفقهي من المذاهب السنية المعروفة إلى غيرها، قصد تققيق هذا الاختيار من جانب، وابتغاء المواءمة بين الفقه ومبادئ

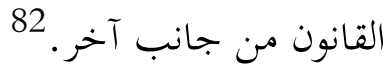

بيْدَ أننا نلاحظ أن الأستاذ السنهوري جعل الشريعة الإسلامية المصدر الثالث من مصادر التنقيح للتقنين المصري القديم في مشروعه النظري، لكن في مشروعه العملي جعل الفقه الإسلامي المصدر الثاني لهذا التنقيح. والذي يلفت النظر أكثر استبداله (الفقه الإسلامي) بـ (الشريعة الإسلامية)، فكأنه تنبه أخيرا إلى وجه الخلاف بين الفقه الذي هو من كسب البشر وبين الشريعة التي هي من وحي الله تعالى، بيد أنه بقي في عباراته دوما يردد الدعوة إلى (تطوير الشريعة الإسلامية)، وإن كان يستعمل أيضا (تطوير الفقه الإسلامي).. فُ(تطوير الشريعة) اصطلاح غير دقيق، بل إذا أخذنا بالاعتبارات الدقيقة انطوى على مدلولات لا تليق بالشريعة الإسلامية، مما يؤكد أن الأستاذ السنهوريّ لم يكن يريد بها إلاًّ الثقافة الفقهية أو الثناقف الفقهي الحضاري تحت راية الإسلام.

وفي بجال هذا التطوير نجد نزوعا قوياً من الأستاذ السنهوري إلى تطوير الفقه الإسلامي على أسلوب الفقه الغربي ومنواله، ومن الناحية الموضوعية حاول أن يجعل القانون محكاً لدراسة الشريعة بترديداته الدعوة

$$
\begin{aligned}
& 80 \\
& 81 \text { انظر: ما كته فتحي الدريني في مقدمة كتاب: نظرية الباعث وأثرها في العقود والتصرفات في الفقه الإسلامي الكيلاني، عبد الله إبراهيم، }
\end{aligned}
$$

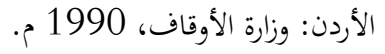

$$
\begin{aligned}
& 82
\end{aligned}
$$


إلى (دراسة الشريعة في ضوء القانون)، كما أنه صرَّح في دائرة (قانون العلاقات) بأنه لا بد أن يطور الفقه الإسلامي على شاكلة القانون منعاً لزعزعة استقرار العلاقات القانونية بين الدول.

ومن هنا جاءت دعوته لدراسة تاريخ تطور الفقه الإسلامي ومتابعة السير الاجتهادي لتنتظم في حلقات تطوير الفقه الإسلامي بعد معرفة منهجه. بل صرح -في كتابه (الخلافة)- أن تطبيق الشريعة الإسلامية بين المسلمين متعذر إلا بعد إدخال ما يستلزهه التطور في بعض أحكامه، مع إثباته النظري في تنقيح القانون- صلاحية الشريعة في حالتها الراهنة لأن يستمد منها المشرع المصري أحكاماً كثيرة. و تأتي أهمية (الإجماع) في كونه مفتاحاً لهذا التطوير في نظر الأستاذ السنهوري، فالإجماع نفسه مرَّ بأطوار وتطور من كونه أمرا لاشعوريا يعتاد عليه الناس، إلى كونه أمرا لازما عن القصد، ويمكن تطويره إلى تنظيم قانوني يؤدي دور التقنين في العصر الراهن.

وعند استقراء الوسائل التي ارتآى إليها الأستاذ السنهوري ليجعلها دعائم الدعوة إلى مصدرية الشريعة الإسلامية للقانون يمكنا الوقوف على العناصر الآتية:

- إن الاستمداد من الشريعة الإسلامية يكهد للاستقلال السياسي والقانوني والفقهي في البلاد العربية والإسلامية. 83

$$
\text { - إن الشريعة الإسلامية هي عرف البلد.84 - }
$$$$
\text { - إن الشريعة الإسلامية سبيل وحدة الأمة الإسلامية. } 85
$$

- الاعتبارات العلمية النابعة من رقي الشريعة الإسلامية وتقدمها على ما سواها من المنظومات. 86 وقد أعاد هذه الاعتبارات العلمية إلى ناحيتين اثنتين:

83

84 Saleh, Nabil. "Civil Codes Of Arab Countries; The Sanhuri Codes", P163.

$$
\begin{aligned}
& 85
\end{aligned}
$$

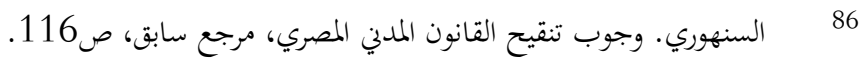


أ. ترقية مبادئ القانون المصري من طريق عرض النظريات العامة - التي تتمشى على جميع نواحي

القانون - على الشريعة الإسلامية. على أن هناك مبادئُ قانونيةً تختلف درجة اعتبارها في التقنينات الحديثة، فيقف المقنن المصري متردداً في درجة الأخذ بها، فيستطيع أن يستعين بالشريعة الإسلامية للبتِّ فيها.

ب. سدُُ وجوه النقص الموجودة في القانون القديم، فهناك أحكام تنقص هذا التشريع، فيمكن ملأ هذا الفراغ بأحكام الشريعة الإسلامية، وقد يكون القضاء المصري قد ملأه واتفق مع الشريعة، فيسجل في تقنينا الاستناد إلى القضاء والشريعة الإسلامية في استقاء هذه الأحكام. 87

وعلى حين أننا نجده يملأ الفراغ بأحكام الشريعة الإسلامية فيما أخذت أحكامه من مصادر أخرى، نجده يشترط ملاءمة مبادئ القانون فيما مصدره هو الشريعة الإسلامية.88 فالشريعة الإسلامية تكمل القانون فيما هو ناقص فيه، وتوافقه فيما هو مستوٍ فيه على سوقه. 89

هذا وقد تفاوت الباحثون في تقويم هذا المشروع، فذهب الأستاذ محمد محمد حسين والأستاذ عباس حسني محمد إلى أن هذا المشروع فيه مخالفة واضحة للشريعة الإسلامية، بينما ذهب الأستاذ محمد عبد الجواد وفيصل محمود العتبان والدكتور محمد عمارة إلى تقديره بأنه تمهيد لتطبيق الشريعة الإسلامية، بل أدرجه الأستاذ عمارة في دائرة مشروع أسلمة القانون.

وقد انطلق الفريق الأول في موقفهم ذلك من جملة انتقادات، يمكن إجمالها فيما يأتي:

87

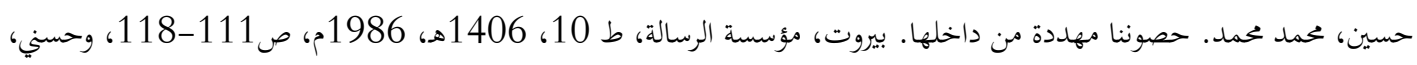
88

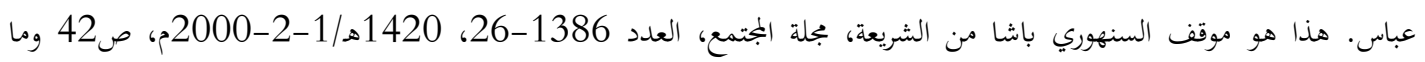

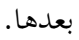

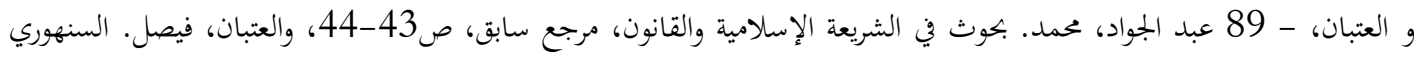

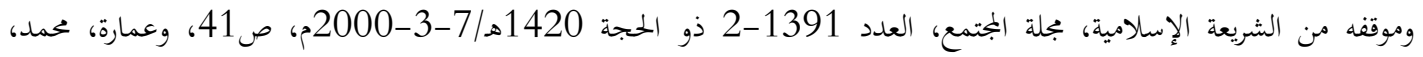

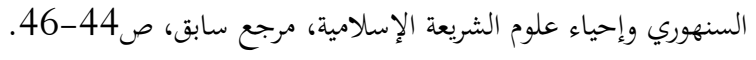


1. إن دعوته إلى تطوير الشريعة الإسلامية في أسلوب القانون الحديث والمواءمة بينها وبين القانون ودراستها في ضوء القانون يشم منها تغيير الشريعة الإسلامية بحيث تكون مشوهة المعالم، غير مرهوبة

2. إذا كان السنهوري هو واضع القانون فقد نصت المادة الأولى من هذا القانون على "أن النصوص التشريعية تسري على جميع المسائل التي تناولما في لفظها أو فحواها. فإذا لم يوجد نص تشريعي حكم القاضي بمقتضى العرف، فإذا لم يوجد فبمقتضى الشريعة الإسلامية، فإذا لم يوجد فبمقتضى مبادئ القانون الطبيعي وقواعد العدالة". 91 وهذا النص يسيء إلى الشريعة في جوانب منها: تقديم العرف على الشريعة الإسلامية، وافتراض أن الشريعة ناقصة، فيأمر بالرجوع إلى قواعد القانون الطبيعي وقواعد العدالة إذا لم تسعف الشريعة بالحكم.

3. اعتذر السنهوري بأن الشريعة الإسلامية لا يمكن تطبيقها قبل دراستها في ضوء القانون. وهذا فيه

إساءة إلى الشريعة من حيث إن الله أمر بتطبيقها وإن لم تدرس دراسة مستفيضة. 92

لكن يخفف من وطْأة هذه الانتقادات ما سبق ذكره من أن الشريعة الإسلامية في إطلاقات السنهوري لا تعني الوحي الإلهي المعصوم، وأنه لم يكن هو واضع القانون، بل منقحاً له برفقة زميله الفرنسي لامبير. ثم إن تطبيق الشريعة لا بلَّ أن يكون عن علم ودراية ودراسة، 93 وحديث القضاة ثلاثة معروف، لكن المستنكر هو تعليق التطبيق على دراستها في ضوء القانون الحديث.

ووقف الفريق الثاني موقف الدفاع عن السنهوري آخذين بنظر الاعتبار الملابسات السياسية والظروف القانونية التي أحاطت هذذا المشروع على طول عهلد، فيقول الأستاذ محمد عبد الجواد: "الدول العببية حين

$$
\begin{aligned}
& 90 \\
& 91 \\
& 92
\end{aligned}
$$

9393

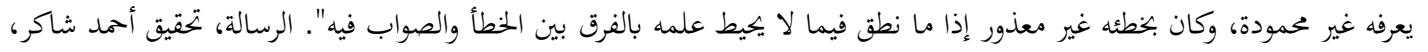

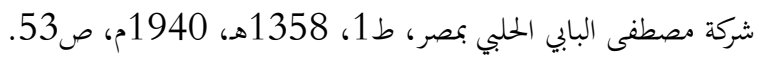


كانت تستدعيه لوضع مشروعات قوانينها، كانت -بحكم ظروفها الخاصة، واستقلالها الحديث، ورغبتها في استكمال مقوماتحا- بإصدار القوانين والتشريعات الضرورية لذلك، كانت، لكل ذلك، في عجلة من أمرها، ولا تملك الوقت الكافي لوضع قوانين من الشريعة الإسلامية... وقد نصحنا -السنهوري- مراراً بأن لا نفكر في وضع مشروعات قوانين من الفقه الإسلامي قبل أن نتفرغ لدراسته عشر سنين على الأقل، حتى نستطيع أن نفهمه فهما يمكننا من صياغة قواعده في صورة القوانين". 94

وقد اتخذ الأستاذ عمارة من مذكرات السنهوري الشخصية حكمه على مشروعه بأنه يمهد الطريق لأسلمة القانون، وربما اقتبس الفقرات التي يثني فيها الأستاذ السنهوري على الشريعة الإسلامية للدلالة على ذلك. والذي يبدو أن الحكم على هذا المشروع، إنما يتم انطلاقا من دراسة المشروع ذاته، أما مذكرات السنهوري الشخصية فلا يمكن أن تتدخل في الحكم على المشروع، إذ لا دلالة مع الصراحة، لا سيما إذا علمنا أن في هذه المذكرات ذاهما ما يؤكد أن تقنين الشريعة كان حلما من أحلام السنهوري لم يشقَّ طريقه إلى الحياة. كما أن اقتباس النصوص التي تثني على الشريعة للدلالة على ذلك يمكن وصفه بأنه يؤدي إلى نظرة جزئية لا تتراءى إلى نقد المشروع كلاًّ واحداً، فإذا كان السنهوري يصف الشريعة الإسلامية بأها نور وهداية وأنَّ من أحكامها ما هو صالح للتطبيق فقد وصف الفقه الفرنسي بأنه "التكأة التي عليها نرتكز، والنور الذي لِّري به فتدي، ولا زلنا مغمورين بفيضه حتى اليوم". 95 ولئن كان الأستاذ محمد عمارة ينطلق في الثناء على هذه المشاريع من زاوية تطوير السنهوري درجة الاقتباس من الشريعة الإسلامية على التدرج، وبناءً على التفاوت الكبير الملحوظ بين التقنين المصري وبين التقنينين العراقي والسوري، 96 فإنه لا بد أيضا من ملاحظة ما ضيَّقه السنهوري في هذين التقنينين من نطاق نفوذ (بجلة الأحكام العدلية) العثمانية المطبَّقة في البلدين. على أن لجنة من فقهاء الشريعة والقانون في سورية

$$
\begin{aligned}
& 94 \\
& 95
\end{aligned}
$$

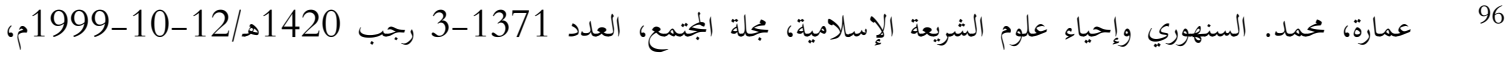
ص40.41-40. 
كانوا في صدد إعداد قانون مدني مستمد من الشريعة الإسلامية، فحدث الانقلاب في الحكم وأوقف مشروع اللجنة، وجاءوا بمشروع السنهوري.

يقول الأستاذ مصطفى الزرقا: "قد كنا نبغي أن تكون هذه السلسلة الفقهية التي نصوغها وهي "الفقه الإسلامي في ثوبه الجديد" تمهيداً لقانون مدني حديث نخرجه في سورية مستمداً من الفقه الإسلامي..غير أننا ونحن في هذا الطريق، وأبصارنا معلقة بنهايته، ووزارة العدل السورية تكلف الإخصائيين بوضع قانون مدني مستمد من الفقه الإسلامي، واف بالحاجات الزمنية الجديدة، فوجئنا بإصدار القانون المدني السوري في عهد الانقلاب العسكري الأول الذي حدث لدينا في 30 آذار 1949م، وكان صدور هذا القانون بمساعي السيد أسعد الكوراني الذي ولاه زعيم الانقلاب -حسني الزعيم- وزارة العدل السورية. فقد اهتبل السيد الكوراني فرصة ذلك العهد الانقلابي والحكم الإرهابي، وأقنع زعيم الانقلاب الذي تولى السلطتين التشريعية والتنفيذية بأن إقامة قانون مدني أجنبي بدلاً من التشريع الإسلامي وفقهه في هذه البلاد هو خير وسيلة لحلود الذكر وعظيم المكانة في نظر الأجانب، وأوهمه أن هذا العمل يجعله كنابليون الذي كان القانون المدني الفرنسي أكثر تخليداً له من فتوحاته. وقد وجدوا أن القانون المدني المصري الجديد يحقق هذا الغرض لأنه أجنبي أوروبي المصادر، فأصدروه بين عشية وضحاها بجرَّة قلم". 97 لذا يرى أن تقديم اعتماد الشريعة على اعتماد العرف في القانون السوري كان لتهدئة وهمية للنفوس، و"واضح أن هذا التقديم والتأخير لا يقدم ولا يؤخر شيئاً بالنسبة إلى الشريعة الإسلامية.. ذلك لأن النص على اعتماد الشريعة الإسلامية يدخل فيه الاعتماد على العرف، لأن العرف من أهم المستندات التي توجب نصوصُ الشريعة وفقهائها اعتمادَها ورعايتَها.. فيكون ذكر اعتماد العرف بعد مبادئ الشريعة من قبيل الحشو الذي لا فائدة منه إلا تشويش الفهم"، أما تقديم العرف عليها كما في القانون المصري فإنه من قبيل التدرج من الأخص إلى الأعم. 98

والذي يمكن أن نخلُص إليه في خاتمة هذا البحث أن هذا المشروع إذا نظرنا إليه من ناحية الصِّنعة والأسلوب والتطور ومن منظور قانوين بحت، أمكن وصفه بأنه من المشاريع القانونية الفذَّة، فلا تنقصه محمدة من هذا الجانب. وإذا وضعناه في ميزان الشريعة الإسلامية فإنه لا يتسنى وصفه بأنه قانون إسلامي، لأنه نابع

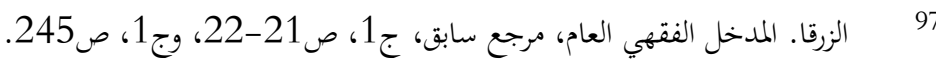

$$
\begin{aligned}
& 98 \text { 9 الزرقا. القانون المدني السوري، مرجع سابق، ص13. }
\end{aligned}
$$


أصلاً من مبادئ القانون الحديث، كما أنَّه لمُ يلتزم عملياً بكثير من أحكام الشريعة الظاهرة، فضلاً عمَّا اشتمل عليه من تقديم القوانين الوضعية والأعراف البشرية على الشريعة الإسلامية، لذا فإن نموذجه لا يمكن أن يكون نواة لأسلمة القانون أو تطوير الفقه الإسلامي، بل الأجدر بالمسلمين أن يصدروا عن منهجية

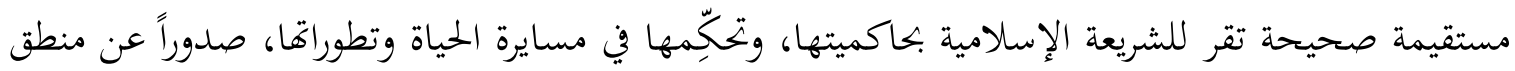

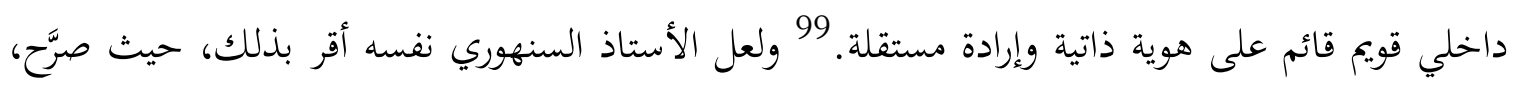
بعد عشرين سنة من صدور التقنين المصري، بأن هذا التقنين الجديد لا يزال يمثل نموذج الحضارة الغربية، لا الفقه الإسلامي.

وليس يعني ذلك أن السنهوري هو المستورد الأول للقوانين الوضعية الأجنبية إلى البلاد الإسلامية، بل تمَّ وضع اللبنة الأساسية لذلك منذ إصدار التنظيمات في الدولة العثمانية سنة 1839م، حتى أخذت حيزها الفعليّ سنة 1860م بإنشاء المحاكم النظامية، وهذا يعني أن القوانين الوضعية قد غُرست فسائلها في هذه البلاد قرابة تسعين سنةً قبل تنفيذ العمل بقوانين السنهوري. والإنصاف يقتضينا أن نؤكد أن الأستاذ السنهوري لم يكن يسعه بككم الظرف السياسي السائد آنذاك أن يستقلَّ باستلهام القوانين، إذلم يكن إلاًّ قريناً للأستاذ (لامبير) القانوين الفرنسي الذي عهد إليه معه وضع القانون المصريّ. على أنَّ في إعراض الأستاذ السنهوري عن الإفادة من القانون الإنجليزي بحجة غرابته عن المصريين برهاناً واضحاً على أنَّ مصركانت تشريعاهما وقتئذٍ متطفلةً على تشريعات فرنسا المنافسة الثقافية للانجليز، وإلاًّ فإن القانون الفرنسي تركي

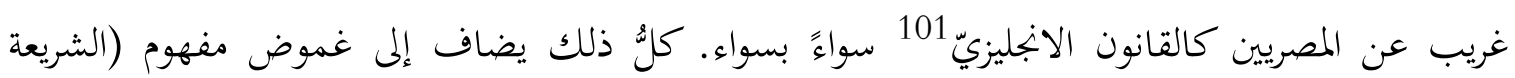
الإسلامية) في إطلاقات السنهوريّ، فهي في رؤيته غير التي تتبادر إلى الأذهان، الأمر الذي كسى دعوته إلى الاقتباس من الشريعة - في مشروعه- ثوبَ الإجمال والاحتمال، فيكون الدارس في وَهْمٍ لا ينقطع حين يعيش

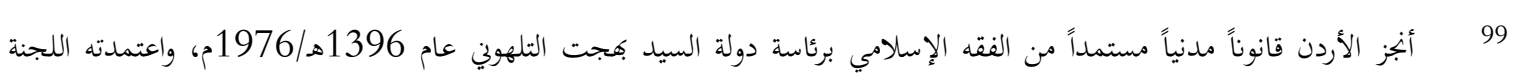

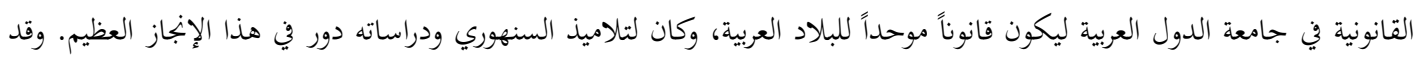

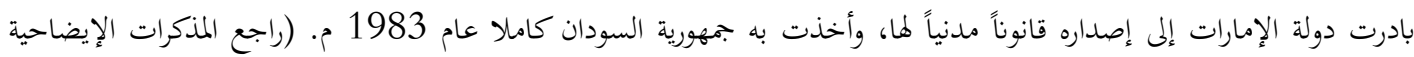

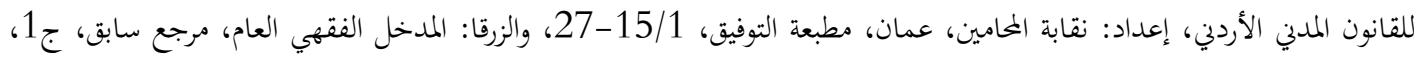

100 Enid Hill, SANHURI AND ISLAMIC LAW ,p.186.

ص303-304).

$$
\text { السنهوري. وجوب تنقيح القانون المدني المصري، مرجع سابق، ص44. }
$$


مع عباراته، ويتعذر عليه تقديرها التقدير السويَّ، سواءٌ ذلك فيما أثنى فيه على الشريعة وفيما أوْهَمَ منتقديه بعضَ الإساءة إليها. وهذا ما جعل موقف السنهوري باشا من الشريعة مغشياً بغير يسير من الغموض في تقنينه، في المراحل النظرية والعملية، على الرغم من وضوح دعوته إلى تطبيق الشريعة في كتاباته الأخرى وفي أوراقه الشخصيَّة. 